\title{
Comparison of ground beetle (Coleoptera, Carabidae) assemblages in tillage and no-tillage cultivation of cereals crop
}

\author{
Porównanie zgrupowań biegaczowatych (Coleoptera, Carabidae) \\ w orkowej i bezorkowej uprawie zbóż
}

\author{
Agnieszka Kosewska*
}

\begin{abstract}
Summary
The objective of the research was to compare the species composition and structures of ground beetle assemblages in tillage and no-tillage cultivation of cereals crop. We also tried to determine the life parameters of Carabidae, which illustrate the best an impact of using deep plowing on beneficial entomofauna. The observations were carried out in north-eastern Poland, near Olsztyn in $2011-2012$. The fields of triticale and wheat cultivated in the traditional system as well as fields of triticale and barley cultivated in the no-tillage cultivation system were selected for the research. Based on the collected results it was concluded that plowing might have an impact on reducing the number of Carabidae species. Simplifying the growing system and using no-tillage cultivation increases the number of medium zoophages and hemizoophages on cultivated fields.
\end{abstract}

Key words: carabid beetles; assemblages; soil tillage; ploughing

\section{Streszczenie}

Badania miały na celu porównanie składu gatunkowego i struktur zgrupowań biegaczowatych w zbożach uprawianych systemem orkowym i bezorkowym. Próbowano również określić parametry życiowe Carabidae, które najlepiej opisują oddziaływanie stosowania orki głębokiej na entomofaunę pożyteczną. Obserwacje prowadzono w Polsce północno-wschodniej, w okolicach Olsztyna, w latach 2011-2012. Do badań wybrano pola pszenżyta i pszenicy uprawiane w tradycyjnym systemie orkowym oraz pola pszenżyta i jęczmienia uprawiane w systemie bezorkowym. W wyniku przeprowadzonych badań stwierdzono, że stosowanie orki może mieć wpływ na zmniejszenie liczby gatunków Carabidae. Uproszczenia w postaci uprawy bezorkowej przyczyniają się do zwiększenia liczebności średnich zoofagów i hemizoofagów na polach uprawnych.

Słowa kluczowe: biegaczowate; zgrupowania; uprawa gleby; orka

Uniwersytet Warmińsko-Mazurski w Olsztynie

Katedra Entomologii, Fitopatologii i Diagnostyki Molekularnej

Prawocheńskiego 17, 10-720 Olsztyn

*corresponding author: a.kosewska@uwm.edu.pl 


\section{Wstęp / Introduction}

Od wielu lat prowadzone są badania nad znaczeniem różnego typu uproszczeń w uprawie gleby. Brane są pod uwagę głównie takie zagadnienia, jak szeroko rozumiana ochrona środowiska naturalnego oraz aspekt ekonomiczny. Kompleksowa ocena tego typu agrotechniki jest jednak trudna, ze względu na złożoność czynników mogących mieć wpływ na wyżej wymienione aspekty. Grupą często wykorzystywaną do różnego typu badań środowiskowych, pomagającą określić stopień zmian siedlisk są chrząszcze z rodziny biegaczowatych (Kotze i wsp. 2011). Ze względu na ich różnorodność, łatwość pozyskania oraz dużą wrażliwość poszczególnych gatunków lub grup ekologicznych na oddziaływanie czynników zewnętrznych, są one doskonałymi bioindykatorami (Irmler 2003; Rainio i Niemelä 2003) zarówno w siedliskach o niewielkim wpływie antropopresji, jak również użytkowanych rolniczo (Kromp 1999; Holland i Reynolds 2003; Holland 2004; Twardowski 2010; Kosewska i wsp. 2014, 2016; Nietupski i wsp. 2015; Schwerk i Dymitryszyn 2017), czy zdegradowanych (Kędzior i wsp. 2017).

Celem pracy było porównanie struktury zgrupowań biegaczowatych w zbożach uprawianych systemem orkowym i bezorkowym. Podjęto próbę wskazania parametrów życiowych Carabidae, które najlepiej opisują oddziaływanie stosowania orki głębokiej na entomofaunę pożyteczną.

\section{Materiały i metody / Materials and methods}

Badania prowadzono w Polsce północno-wschodniej, w okolicach Olsztyna (UTM DE 65). Do badań wybrano pola wielohektarowe (60-80 ha) z uprawą pszenżyta i pszenicy $\mathrm{w}$ tradycyjnym systemie orkowym oraz uprawą pszenżyta i jęczmienia w systemie bezorkowym, stosując różnego typu agregaty uprawowe spulchniające i mieszające glebę, bez odwracania skiby. Na każdym z pól wyznaczono po 3 obszary oddalone od siebie o minimum 100 metrów, na których założono po 6 zmodyfikowanych pułapek Barbera, oddalonych jedna od drugiej o 20 metrów i ustawionych w linii prostej biegnącej do środka pola. Pułapki opróżniano co 2 tygodnie. Biegaczowate odławiano od kwietnia do października w latach 2011-2012. Na okres żniw i przygotowania gleby pod nową uprawę pułapki były usuwane (2 tygodnie).

Zebrany materiał przeanalizowano pod kątem różnic w składzie gatunkowym, liczebności, indeksach bioróżnorodności oraz strukturach zgrupowań Carabidae. Po oznaczeniu do gatunku (Hůrka 1996) zaklasyfikowano je do różnych grup ekologicznych na podstawie preferencji troficznych, wielkości ciała i typu rozwojowego (Larsson 1939; Thiele 1977; Aleksandrowicz 2004). Przy opracowaniu wyników posłużono się wskaźnikami ogólnej różnorodności gatunkowej Shannona (H') (Log Base 2,718), równomierności Pielou (J') oraz bogactwa gatunkowego Simpsona (D). Różnice składu gatunkowego i liczebności zgrupowań biegaczowatych dwóch badanych systemów uprawy gleby testowano za pomocą niemetrycznego skalowania wielowymiarowego, w którym jako wskaźnik podobieństwa użyto indeksu Bray-Curtisa, a istotność statystyczną potwierdzono za pomocą analizy wariancji podobieństwa (ANOSIM). Ze względu na brak rozkładu normalnego zależność pomiędzy typem uprawy gleby a badanymi parametrami o ewentualnej wartości bioindykacyjnej określano za pomocą uogólnionego modelu liniowego (GLM - generalized linear model) dla rozkładów Poissona.

\section{Wyniki i dyskusja / Results and discussion}

W wyniku przeprowadzonych badań w ciągu dwóch lat odłowiono 34397 osobników należących do 78 gatunków Carabidae (tab. 1). W uprawach zbóż prowadzonych systemem bezorkowym odłowiono 16972 osobniki należące do 70 gatunków, natomiast $\mathrm{w}$ tradycyjnym systemie orkowym odnotowano 17425 osobników z 64 gatunków. Zaobserwowano statystycznie istotne różnice w liczbie odłowionych osobników w badanych systemach uprawy gleby (tab. 2). Z wcześniejszych badań nad tą tematyką nie można wyciągnąć jednoznacznych wniosków, gdyż część autorów wykazywała negatywny wpływ orki na liczebność i bioróżnorodność biegaczowatych (Cárcamo i wsp. 1995; Breavult i wsp. 2007; Hatten i wsp. 2007; Twardowski 2010; Kosewska i wsp. 2014; Skłodowski 2014), część pozytywny (Barney i Pass 1986; Hole i wsp. 2005), a część brak wpływu (Purvis i Fadl 2002; Andersen 2003). W przypadku uprawy bezorkowej w przeprowadzonych badaniach, niezależnie od gatunku uprawianego zboża liczebność Carabidae była podobna (rys. 1). W uprawie orkowej natomiast gatunek uprawianego zboża był czynnikiem determinującym liczebność biegaczowatych, i w uprawie pszenicy była ona statystycznie istotnie wyższa niż w uprawie pszenżyta. W badaniach nad biegaczowatymi wielu autorów wykazuje wpływ rodzaju uprawianej rośliny na liczebność i bogactwo gatunkowe Carabidae (Baguette i Hance 1997; Kromp 1999; Holland i Luff 2000; Twardowski i Pastuszko 2008; Kosewska i wsp. 2009, 2016; Eyre i wsp. 2013). Liczba odłowionych gatunków biegaczowatych w badanych uprawach w latach badań wahała się między $41 \mathrm{w}$ uprawie orkowej pszenicy, a $51 \mathrm{w}$ orkowej uprawie pszenżyta i bezorkowej jęczmienia (tab. 1). Nie odnotowano statystycznie istotnych różnic dotyczących liczby odłowionych gatunków pomiędzy badanymi sposobami uprawy gleby (tab. 2). Również w przypadku wskaźników różnorodności gatunkowej różnice nie były statystycznie istotne. Wskaźnik różnorodności Shannona (H') osiągał niezbyt wysokie wartości, w większości przypadków nie przekraczające 2 (tab. 1). Tylko w przypadku orkowej uprawy pszenżyta 
Tabela 1. Skład gatunkowy, liczebność oraz wskaźniki opisujące zgrupowania biegaczowatych zbóż uprawianych w systemie orkowym i bezorkowym

Table 1. Species composition, abundance and indices describing the ground beetle assemblages in tillage and no-tillage cultivation system of cereals

\begin{tabular}{|c|c|c|c|c|c|c|c|c|}
\hline \multirow{3}{*}{$\begin{array}{r}\text { System uprawy - Cultivation system } \\
\text { Rok - Year }\end{array}$} & \multicolumn{4}{|c|}{ Orkowy - Tillage } & \multicolumn{4}{|c|}{ Bezorkowy - No-tillage } \\
\hline & \multicolumn{2}{|c|}{2011} & \multicolumn{2}{|c|}{2012} & \multicolumn{2}{|c|}{2011} & \multicolumn{2}{|c|}{2012} \\
\hline & $\begin{array}{c}\text { pszenżyto } \\
\text { tritical }\end{array}$ & $\begin{array}{l}\text { pszenica } \\
\text { wheat }\end{array}$ & $\begin{array}{c}\text { pszenżyto } \\
\text { tritical }\end{array}$ & $\begin{array}{l}\text { pszenica } \\
\text { wheat }\end{array}$ & $\begin{array}{c}\text { pszenżyto } \\
\text { tritical }\end{array}$ & $\begin{array}{c}\text { jęczmień } \\
\text { barley }\end{array}$ & $\begin{array}{c}\text { pszenżyto } \\
\text { tritical }\end{array}$ & $\begin{array}{l}\text { jęczmień } \\
\text { barley }\end{array}$ \\
\hline 1 & 2 & 3 & 4 & 5 & 6 & 7 & 8 & 9 \\
\hline Acupalpus parvulus (Sturm, 1825) & 0 & 0 & 0 & 1 & 0 & 0 & 0 & 0 \\
\hline Agonum fuliginosum (Panzer, 1809) & 0 & 0 & 2 & 0 & 0 & 0 & 0 & 0 \\
\hline Agonum muelleri (Herbst, 1784) & 0 & 0 & 0 & 0 & 0 & 0 & 1 & 0 \\
\hline Agonum sexpunctatum (L., 1758) & 0 & 0 & 0 & 0 & 0 & 1 & 0 & 0 \\
\hline Agonum viduum (Panzer, 1797) & 0 & 0 & 0 & 1 & 0 & 1 & 1 & 1 \\
\hline Amara aenea (Degeer, 1774) & 2 & 1 & 1 & 2 & 0 & 7 & 0 & 0 \\
\hline Amara bifrons (Gyllenhal, 1810) & 0 & 1 & 1 & 0 & 0 & 1 & 0 & 1 \\
\hline Amara communis (Panzer, 1797) & 2 & 1 & 1 & 2 & 1 & 5 & 7 & 0 \\
\hline Amara consularis (Duft., 1812) & 0 & 0 & 0 & 0 & 1 & 0 & 0 & 0 \\
\hline Amara convexior Stephens, 1828 & 1 & 0 & 1 & 6 & 5 & 8 & 2 & 2 \\
\hline Amara eyrynota (Panzer, 1797) & 0 & 0 & 0 & 0 & 0 & 0 & 0 & 1 \\
\hline Amara familiaris (Duft., 1812) & 0 & 0 & 0 & 0 & 0 & 0 & 1 & 0 \\
\hline Amara littorea Thomson, 1857 & 0 & 0 & 1 & 0 & 0 & 0 & 0 & 0 \\
\hline Amara lunicollis Schiodte, 1837 & 0 & 0 & 0 & 0 & 0 & 2 & 4 & 6 \\
\hline Amara nitida Sturm, 1825 & 0 & 0 & 0 & 0 & 0 & 0 & 0 & 1 \\
\hline Amara ovata (Fabricius, 1792) & 3 & 22 & 0 & 78 & 13 & 30 & 1 & 26 \\
\hline Amara plebeja (Gyllenhal, 1810) & 11 & 5 & 4 & 17 & 7 & 149 & 15 & 51 \\
\hline Amara similata (Gyllenhal, 1810) & 4 & 7 & 4 & 41 & 16 & 38 & 5 & 14 \\
\hline Amara spreta Dejean, 1831 & 2 & 0 & 1 & 0 & 0 & 0 & 0 & 3 \\
\hline Anchomenus dorsalis (Pont., 1763) & 192 & 827 & 278 & 289 & 565 & 197 & 638 & 144 \\
\hline Anisodactylus binotatus (F., 1787) & 3 & 3 & 5 & 4 & 9 & 8 & 2 & 3 \\
\hline Anisodactylus nemorivagus (Duft.) & 0 & 0 & 0 & 0 & 0 & 0 & 1 & 0 \\
\hline Asaphidion flavipes (L., 1761) & 4 & 2 & 55 & 5 & 10 & 13 & 13 & 107 \\
\hline Badister bullatus (Schrank, 1798) & 0 & 0 & 0 & 0 & 0 & 0 & 1 & 0 \\
\hline Badister lacertosus Sturm, 1815 & 0 & 0 & 1 & 1 & 0 & 0 & 0 & 0 \\
\hline Bembidion guttula (Fabricius, 1792) & 9 & 6 & 16 & 3 & 7 & 2 & 10 & 8 \\
\hline Bembidion lampros (Herbst, 1784) & 12 & 8 & 67 & 25 & 18 & 48 & 17 & 196 \\
\hline Bembidion properans (Steph., 1828) & 8 & 11 & 13 & 26 & 3 & 73 & 2 & 318 \\
\hline Bembidion quadrimaculatum (L.) & 0 & 0 & 3 & 1 & 14 & 3 & 5 & 7 \\
\hline Bembidion tetracolum Say, 1823 & 0 & 0 & 32 & 0 & 0 & 6 & 0 & 13 \\
\hline Blemus discus (Fabricius, 1792) & 0 & 0 & 0 & 5 & 0 & 0 & 0 & 1 \\
\hline Broscus cephalotes (Linnaeus, 1758) & 0 & 0 & 0 & 0 & 3 & 6 & 0 & 19 \\
\hline Calathus ambiguus (Paykull, 1790) & 23 & 12 & 18 & 1 & 5 & 7 & 9 & 0 \\
\hline Calathus cinctus Motschul., 1850 & 16 & 2 & 14 & 0 & 4 & 6 & 4 & 1 \\
\hline Calathus erratus (Sahlberg, 1827) & 3 & 6 & 3 & 0 & 0 & 1 & 0 & 0 \\
\hline Calathus fuscipes (Goeze, 1777) & 122 & 97 & 92 & 35 & 44 & 112 & 74 & 35 \\
\hline Calathus halensis (Schaller, 1783) & 1 & 2 & 0 & 1 & 0 & 6 & 1 & 1 \\
\hline Calathus melanocephalus (L., 1758) & 3 & 2 & 12 & 0 & 5 & 5 & 5 & 3 \\
\hline Carabus cancellatus Illiger, 1798 & 5 & 1 & 1 & 4 & 9 & 0 & 15 & 3 \\
\hline Carabus granulatus Linnaeus, 1758 & 249 & 102 & 198 & 193 & 489 & 26 & 554 & 15 \\
\hline
\end{tabular}




\begin{tabular}{|c|c|c|c|c|c|c|c|c|}
\hline 1 & 2 & 3 & 4 & 5 & 6 & 7 & 8 & 9 \\
\hline Carabus nemoralis O.F. Muller, 1764 & 1 & 4 & 1 & 7 & 1 & 2 & 1 & 0 \\
\hline Chlaenius nigricornis (Fabricius, 1787) & 1 & 0 & 1 & 0 & 0 & 0 & 4 & 0 \\
\hline Clivina collaris (Herbst, 1784) & 0 & 0 & 0 & 0 & 0 & 1 & 0 & 1 \\
\hline Clivina fossor (Linnaeus, 1758) & 1 & 5 & 12 & 0 & 1 & 14 & 2 & 9 \\
\hline Curtonotus aulicus (Panzer, 1797) & 0 & 0 & 1 & 4 & 1 & 0 & 1 & 1 \\
\hline Cychrus caraboides (Linnaeus, 1758) & 0 & 0 & 2 & 0 & 0 & 0 & 0 & 0 \\
\hline Harpalus affinis (Schrank, 1781) & 11 & 15 & 5 & 1 & 100 & 75 & 62 & 13 \\
\hline Harpalus distinguendus (Duft., 1812) & 0 & 1 & 0 & 32 & 0 & 7 & 0 & 0 \\
\hline Harpalus griseus (Duftschmid, 1812) & 1 & 3 & 1 & 1 & 2 & 1 & 3 & 1 \\
\hline Harpalus latus (Linnaeus, 1758) & 1 & 0 & 1 & 0 & 2 & 1 & 1 & 0 \\
\hline Harpalus luteicornis (Duft., 1812) & 10 & 13 & 10 & 18 & 8 & 19 & 17 & 4 \\
\hline Harpalus progrediens Schaub., 1922 & 0 & 0 & 0 & 0 & 1 & 9 & 1 & 2 \\
\hline Harpalus rubripes (Duft., 1812) & 1 & 0 & 0 & 0 & 1 & 0 & 1 & 0 \\
\hline Harpalus rufipalpis Sturm, 1818 & 0 & 0 & 0 & 0 & 0 & 0 & 0 & 1 \\
\hline Harpalus rufipes (Degeer, 1774) & 255 & 253 & 102 & 290 & 445 & 171 & 298 & 78 \\
\hline Harpalus signaticornis (Duft., 1812) & 2 & 2 & 1 & 14 & 0 & 9 & 0 & 1 \\
\hline Harpalus smaragdinus (Duft., 1812) & 0 & 0 & 0 & 1 & 1 & 1 & 0 & 0 \\
\hline Harpalus tardus (Panzer, 1797) & 4 & 4 & 10 & 3 & 4 & 103 & 3 & 4 \\
\hline Limodromus assimilis (Paykull, 1790) & 12 & 47 & 48 & 88 & 11 & 1 & 15 & 2 \\
\hline Loricera pilicornis (Fabricius, 1775) & 25 & 23 & 180 & 114 & 7 & 15 & 44 & 98 \\
\hline Microlestes minutulus (Goeze, 1777) & 0 & 0 & 0 & 0 & 0 & 0 & 0 & 2 \\
\hline Nebria brevicollis (Fabricius, 1792) & 19 & 98 & 67 & 11 & 18 & 7 & 30 & 3 \\
\hline Notiophilus palustris (Duft., 1812) & 25 & 8 & 14 & 0 & 11 & 12 & 6 & 11 \\
\hline Philorhizus sigma (Rossi, 1790) & 0 & 1 & 0 & 1 & 0 & 0 & 0 & 0 \\
\hline Poecilus cupreus (Linnaeus, 1758) & 1439 & 3025 & 231 & 4317 & 2176 & 3416 & 2012 & 1184 \\
\hline Poecilus lepidus (Leske, 1785) & 1 & 0 & 0 & 1 & 1 & 2 & 0 & 54 \\
\hline Poecilus versicolor (Sturm, 1824) & 36 & 46 & 19 & 27 & 59 & 224 & 84 & 113 \\
\hline Pterostichus anthracinus (Ill., 1798) & 1 & 0 & 1 & 0 & 0 & 0 & 0 & 7 \\
\hline Pterostichus diligens (Sturm, 1824) & 0 & 0 & 0 & 12 & 1 & 0 & 1 & 0 \\
\hline Pterostichus melanarius (Illiger, 1798) & 449 & 1249 & 311 & 466 & 318 & 219 & 270 & 473 \\
\hline Pterostichus niger (Schaller, 1783) & 32 & 58 & 90 & 188 & 3 & 0 & 19 & 16 \\
\hline Pterostichus nigrita (Paykull, 1790) & 1 & 1 & 0 & 0 & 0 & 0 & 0 & 0 \\
\hline Pterostichus oblongopunctatus (F.) & 0 & 0 & 2 & 1 & 0 & 0 & 0 & 0 \\
\hline Pterostichus strenuus (Panzer, 1797) & 0 & 4 & 4 & 1 & 1 & 0 & 3 & 1 \\
\hline Pterostichus vernalis (Panzer, 1796) & 1 & 0 & 0 & 2 & 5 & 0 & 4 & 2 \\
\hline Stomis pumicatus (Panzer, 1796) & 4 & 0 & 1 & 1 & 1 & 0 & 1 & 0 \\
\hline Synuchus vivalis (Illiger, 1798) & 1 & 0 & 1 & 0 & 0 & 1 & 0 & 0 \\
\hline Trechus quadristriatus (Schr., 1781) & 47 & 25 & 39 & 45 & 23 & 27 & 21 & 91 \\
\hline $\begin{array}{l}\text { Liczba osobników } \\
\text { Number of individuals }\end{array}$ & 3056 & 6003 & 1979 & 6387 & 4430 & 5098 & 4292 & 3152 \\
\hline $\begin{array}{l}\text { Liczba gatunków } \\
\text { Number of species }\end{array}$ & 47 & 41 & 51 & 47 & 46 & 49 & 50 & 51 \\
\hline $\begin{array}{l}\text { Różnorodność Shannona H' } \\
\text { Shannon's diversity H' }\end{array}$ & 1,95 & 1,616 & 2,783 & 1,462 & 1,79 & 1,576 & 1,876 & 2,309 \\
\hline $\begin{array}{l}\text { Równomierność Pielou J' } \\
\text { Pielou evenness J' }\end{array}$ & 0,507 & 0,435 & 0,708 & 0,38 & 0,468 & 0,405 & 0,479 & 0,587 \\
\hline $\begin{array}{l}\text { Różnorodność Simpsona D } \\
\text { Simpson's diversity D }\end{array}$ & 0,263 & 0,319 & 0,088 & 0,469 & 0,286 & 0,458 & 0,268 & 0,185 \\
\hline
\end{tabular}


Tabela 2. Wyniki testu GLM (uogólnionego modelu liniowego) dla liczebności oraz wybranych parametrów życiowych biegaczowatych Table 2. Results of GLM (generalized linear model) test of significance for abundance and some life traits of ground beetles

\begin{tabular}{|c|c|c|}
\hline Efekt - Effect & $\begin{array}{l}\text { Statystyki Walda } \\
\text { Wald's statistics }\end{array}$ & $\mathrm{p}$ \\
\hline \multicolumn{3}{|c|}{ Liczba osobników - Number of individuals } \\
\hline 1 & 963,7 & 0,000 \\
\hline 2 & 2916,1 & 0,000 \\
\hline \multicolumn{2}{|c|}{ Liczba gatunków - Number of species } & ns. \\
\hline \multicolumn{2}{|c|}{ Różnorodnośc Shannona H - Shannon's diversity H' } & ns. \\
\hline \multicolumn{2}{|c|}{ Równomierność Pielou J' - Pielou evenness J' } & ns. \\
\hline \multicolumn{2}{|c|}{ Różnorodność Simpsona D - Simpson’s diversity D } & ns. \\
\hline \multicolumn{3}{|c|}{ Duże zoofagi - Large zoophages } \\
\hline \multirow{2}{*}{1} & 29,37 & 0,000 \\
\hline & 565,14 & 0,000 \\
\hline \multicolumn{3}{|c|}{ Średnie zoofagi - Medium zoophages } \\
\hline 1 & 989,9 & 0,000 \\
\hline 2 & 2898,6 & 0,000 \\
\hline \multicolumn{3}{|c|}{ Hemizoofagi - Hemizoophages } \\
\hline 1 & 210,93 & 0,000 \\
\hline 2 & 123,87 & 0,000 \\
\hline \multicolumn{3}{|c|}{ Małe zoofagi - Small zoophages } \\
\hline 1 & 55,538 & 0,000 \\
\hline 2 & 461,769 & 0,000 \\
\hline \multicolumn{3}{|c|}{ Wiosenne - Spring breeders } \\
\hline 1 & 1326,4 & 0,000 \\
\hline 2 & 2761,1 & 0,000 \\
\hline \multicolumn{3}{|c|}{ Jesienne - Autumn breeders } \\
\hline 1 & 4,38 & 0,036 \\
\hline 2 & 302,14 & 0,000 \\
\hline
\end{tabular}

1- sposób uprawy gleby - type of tillage, 2 - zboże - cereal, ns. - nieistotne - not significant, p - wartość - p-value

w 2012 roku odnotowano wysoki wskaźnik H’ wynoszący 2,783. Tak wysoka wartość związana była z relatywnie dużą liczbą odłowionych gatunków Carabidae w stosunku do liczby osobników. Wskaźnik równomierności Pielou jest ściśle związany z indeksem Shannona, dlatego też w przypadku wymienionej uprawy odnotowano również jego najwyższą wartość $(0,708)$. Podobne wyniki w uprawie pszenżyta otrzymali Kosewska i wsp. (2009) stwierdzając, że wyższe wartości H' charakterystyczne są dla zgrupowań o bardziej ustabilizowanej strukturze, ale mniej liczebnych. Współczynnik różnorodności Simpsona nadaje mniejsze znaczenie gatunkom występującym pojedynczo w zgrupowaniu, uwypukla natomiast występowanie gatunków pospolitych, najliczniejszych w badanych zbiorach, które prawdopodobnie są bardziej odporne na różnego typu zaburzenia siedlisk.
W przeprowadzonych badaniach wskaźnik D przyjmował najwyższe wartości w orkowej uprawie pszenicy $(0,469)$ i w jęczmieniu uprawianym w systemie bezorkowym $(0,458)$. W tych kombinacjach odnotowano bardzo wysoką liczebność biegaczowatych, ale w obydwu przypadkach jeden gatunek, Poecilus cupreus, stanowił ponad połowę zebranych osobników. Gatunek ten występował licznie na wszystkich badanych polach, jednak w pozostałych przypadkach nie przekraczał 50\% zgrupowania. Do gatunków dominujących na badanych powierzchniach należały również: Pterostichus melanarius, który preferował uprawy orkowe, Harpalus rufipes, Carabus granulatus, który zdecydowanie najliczniej występował w bezorkowej uprawie pszenżyta, niezależnie od roku badań oraz Anchomenus dorsalis (tab. 1). Zarówno gatunki dominujące, jak też pozostały skład gatunkowy 


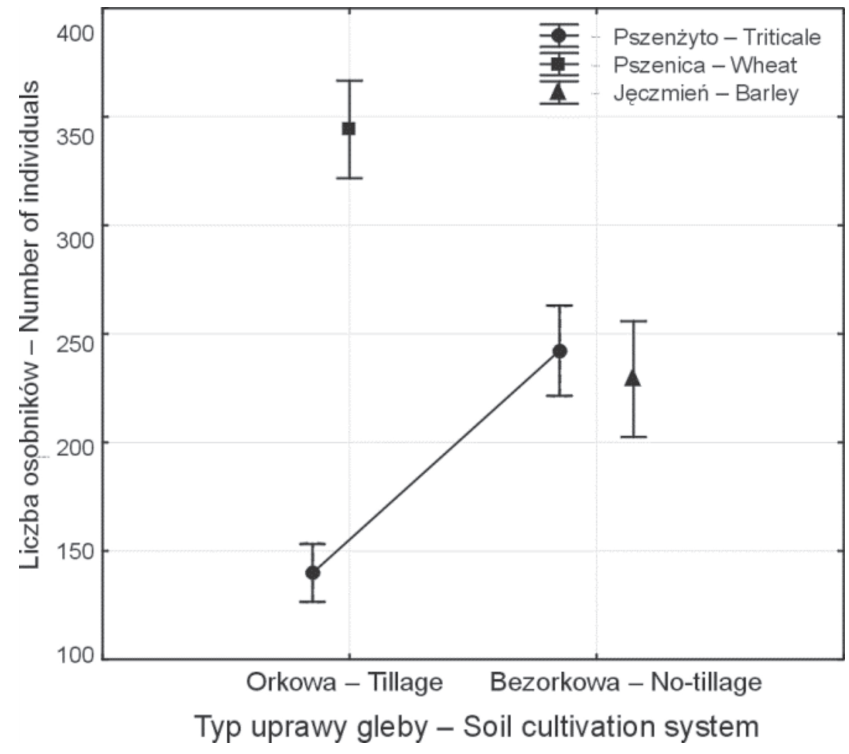

Rys. 1. Średnia liczebność biegaczowatych w zależności od systemu uprawy gleby (orkowy i bezorkowy) w badanych zbożach (•pszenżyto,• pszenica, $\boldsymbol{\Delta}$ jęczmień). Pionowe linie wskazują 0,95 przedziału ufności

Fig. 1. Average abundance of ground beetles depended on studied soil cultivation system (tillage and no-tillage) in studied cereals $(\bullet$ triticale, $\boldsymbol{\bullet}$ wheat, $\boldsymbol{\Delta}$ barley). The vertical lines indicate 0.95 confidence interval

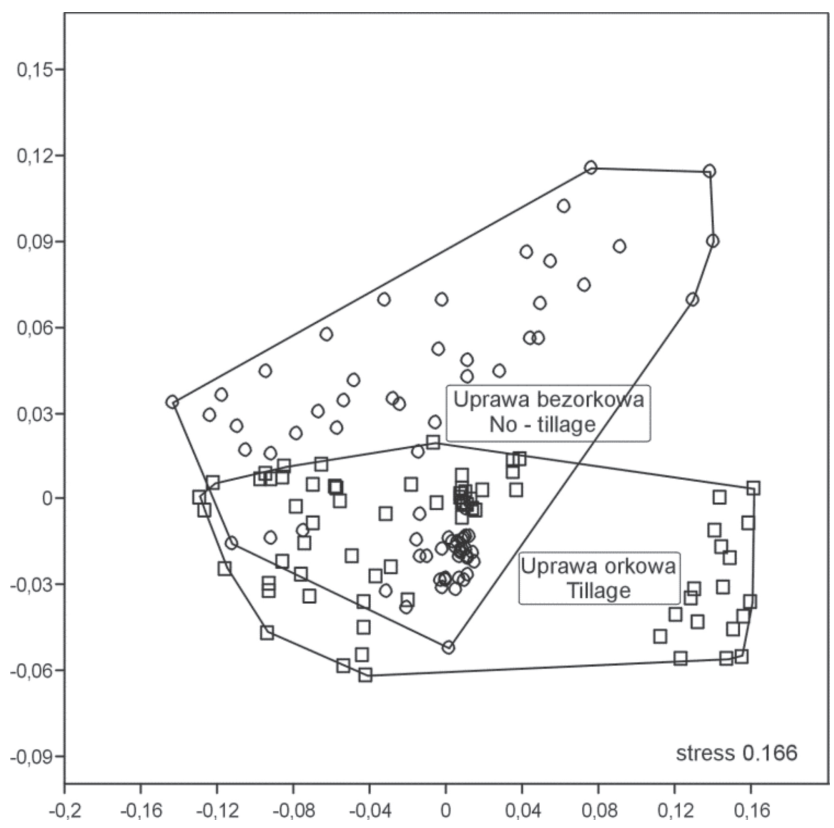

Rys. 2. Diagram niemetrycznego skalowania wielowymiarowego (NMDS) dla badanych zgrupowań Carabidae ( $\square$ - uprawa orkowa, $\bigcirc$ - uprawa bezorkowa)

Fig. 2. Diagram of non-metric multi-dimensional scaling (NMDS) for studied ground beetle assemblages ( $\square$ - tillage, $\bigcirc-$ no-tillage)

Carabidae badanych powierzchni jest typowy dla upraw rolniczych środkowo-wschodniej Europy, co znajduje od- zwierciedlenie w badaniach innych autorów (Tamutis i wsp. 2004; Aleksandrowicz i wsp. 2008; Twardowski i Pastuszko 2008; Gailis i Turka 2014; Nietupski i wsp. 2015; Kosewska 2016; Gailis i wsp. 2017a).

Diagram niemetrycznego skalowania wielowymiarowego (NMDS - non-metric multi-dimensional scaling) ukazuje podobieństwa i różnice w składzie gatunkowym i liczebności Carabidae dwóch badanych systemów uprawy gleby (rys. 2). Zgrupowania biegaczowatych na badanych polach różniły się między sobą w zależności od zastosowanego wariantu uprawy. Wyodrębniono duży zbiór Carabidae wspólnych dla obydwu systemów uprawy i prawdopodobnie wspólnych dla większości agrocenoz, i jednocześnie zaobserwowano również duże zróżnicowanie, które za pomocą analizy ANOSIM zostało potwierdzone jako statystycznie istotne (R: 0,1386; p: 0,001). Stres o wartości 0,166 (rys. 2) świadczy o dobrym dopasowaniu modelu do badanych zgrupowań. Jak podają Lys i Nentwig (1991) pod wpływem zmian w strukturze gleby spowodowanych przez orkę, zmienia się liczebność, skład gatunkowy, a także zachowania poszczególnych gatunków. Przykładowo P. melanarius w przeprowadzonych badaniach preferował uprawy orkowe, podczas gdy Gailis i wsp. (2017b) wykazują go częściej na bezorkowych. Pterostichus niger, jak podaje Skłodowski (2014) szybko kolonizuje obszary po orce głębokiej, co również potwierdzone zostało w przeprowadzonych badaniach.

$\mathrm{W}$ analizie zgrupowań biegaczowatych nie można pominąc ich charakterystyki ekologicznej. Jednymi z ważniejszych parametrów życiowych Carbidae są ich preferencje troficzne i wielkość ciała. Związane jest to przede wszystkim z możliwościami ograniczania przez biegaczowate liczebności szkodników roślin uprawnych (Sunderland 2002). Im większy drapieżca tym jego zapotrzebowanie na pokarm jest większe, a co się z tym wiąże jest bardziej pożądany w agrocenozach. Stąd też szczególną wagę przywiązuje się do zapewnienia optymalnych warunków dla dużych i średnich zoofagów, jako potencjalnych naturalnych wrogów wielu szkodników. W dobie integrowanej produkcji, dbałość o naturalne elementy w ochronie roślin jest rzeczą kluczową. Przeprowadzone w orkowych i bezorkowych uprawach zbóż badania wykazały statystycznie istotne różnice w liczebności poszczególnych grup troficznych (tab. 2). W przypadku dużych i małych zoofagów decydującym czynnikiem różnicującym był gatunek zboża (rys. 3). Prawdopodobnie mikroklimat, jaki stwarzały uprawiane rośliny wraz z zastosowaną agrotechniką były czynnikami determinującymi pojawianie się chrząszczy o różnych rozmiarach ciała. Duże zoofagi preferowały pszenicę w uprawie orkowej, podczas gdy małe zoofagi zasiedlały bezorkowo uprawiany jęczmień. W pszenżycie jedne i drugie pojawiały się w podobnych liczebnościach niezależnie od sposobu uprawy gleby. Jednakże sposób uprawy był głównym czynnikiem różnicującym w przypadku średnich zoofagów. Hemizoofagi natomiast nie reagowały silnie ani na 

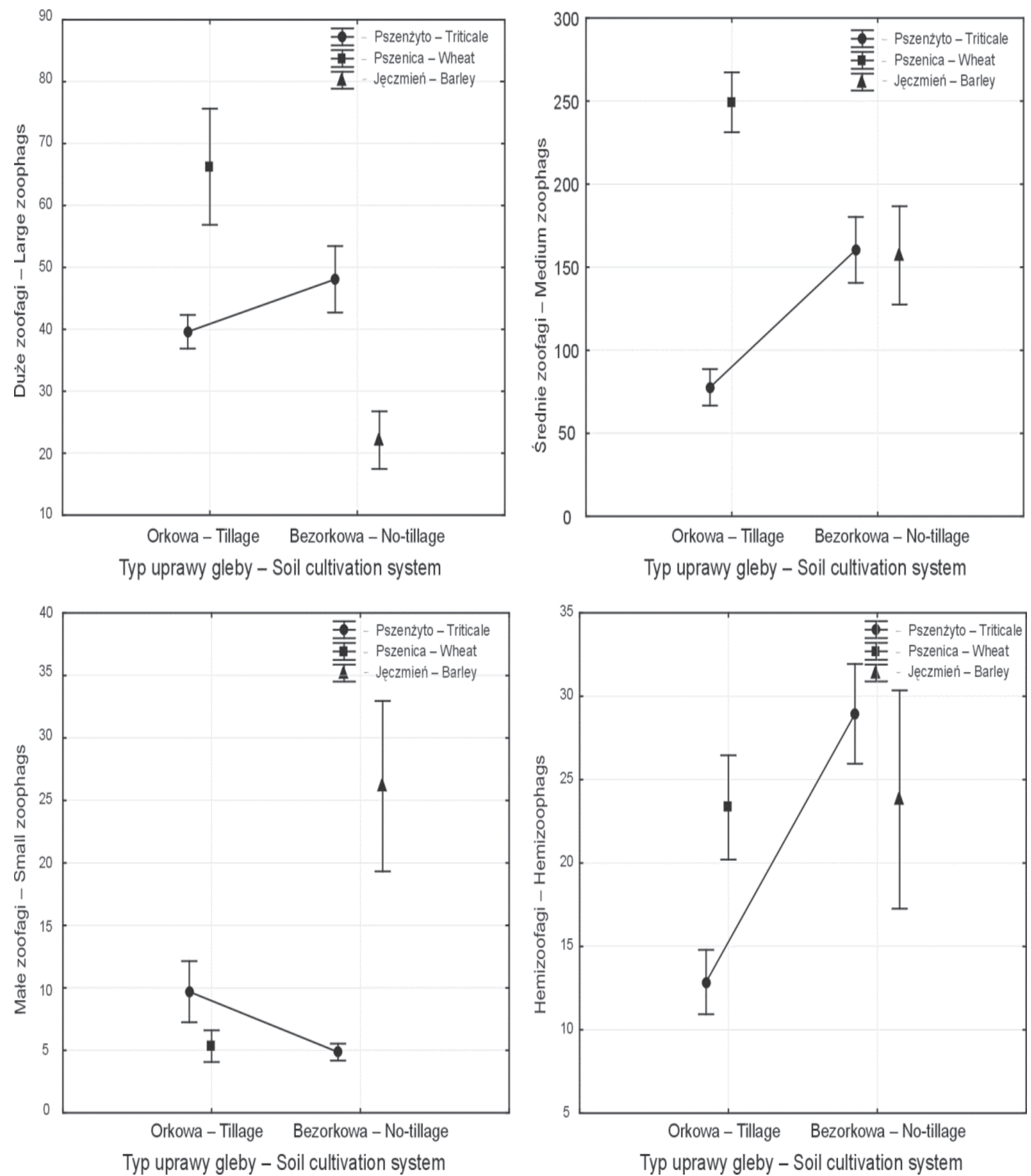

Rys. 3. Średnia liczebność grup troficznych Carabidae w zależności od systemu uprawy gleby (orkowy i bezorkowy) w badanych zbożach (•pszenżyto, •pszenica, $\boldsymbol{\Delta}$ jęczmień). Pionowe linie wskazują 0,95 przedziału ufności

Fig. 3. Average abundance of trophic groups of Carabidae depended on studied soil cultivation system (tillage and no-tillage) in studied cereals ( $\bullet$ triticale, $\bullet$ wheat, $\Delta$ barley). The vertical lines indicate 0.95 confidence interval

sposób uprawy, ani na gatunek uprawianego zboża. Gailis i wsp. (2017b) w swoich badaniach wykazali preferencje biegaczowatych o małych rozmiarach do uprawy orkowej, podczas gdy średnie i duże Carabidae wybierały uprawy uproszczone. Jak podają Thiele (1977) oraz Kędzior i wsp. (2017) środowisko o dużym wpływie antropopresji faworyzuje gatunki o dużej tolerancji ekologicznej i odporności na presję środowiska, co w tym przypadku objawia się niewiel- kimi rozmiarami ciała i hemizoofagizmem. W przypadku typów rozwojowych Carabidae w agrocenozach preferowane są biegaczowate jesienne, jako dłużej pozostające na polu i konsumujące więcej szkodników roślinnych. W przeprowadzonych badaniach zauważyć można, że wiosenny typ rozwojowy Carabidae reagował silniej na sposób uprawy gleby (rys. 4). Dla biegaczowatych jesiennych natomiast istotnym czynnikiem był gatunek uprawianego zboża. 

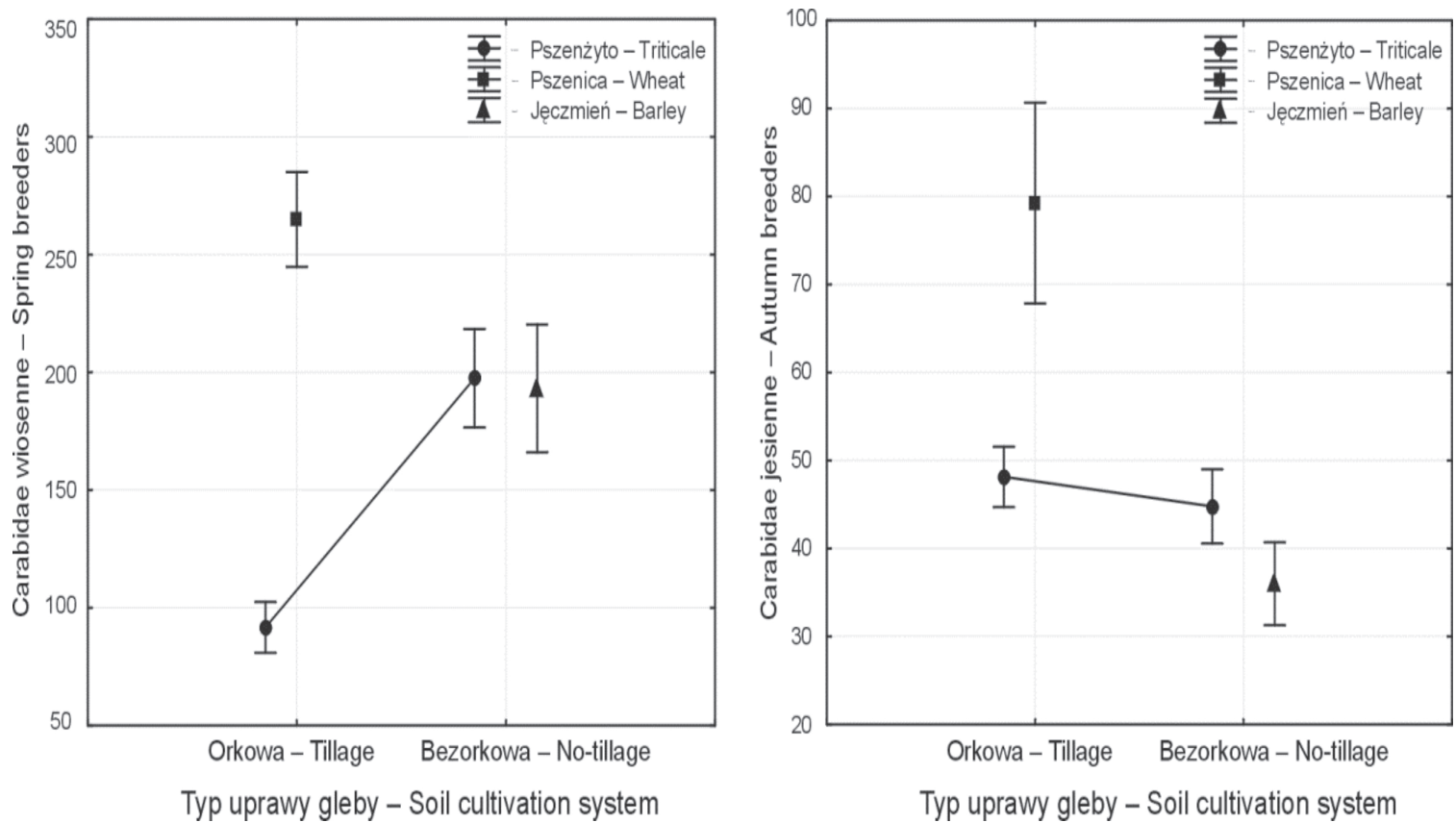

Rys. 4. Średnia liczebność wiosennych i jesiennych Carabidae w zależności od systemu uprawy gleby (orkowy i bezorkowy) w badanych zbożach (•pszenżyto, •pszenica, $\boldsymbol{\Delta}$ jęczmień). Pionowe linie wskazują 0,95 przedziału ufności

Fig. 4. Average abundance of spring breeders and autumn breeders of Carabidae depended on studied soil cultivation system (tillage and no-tillage) in studied cereals ( $\bullet$ triticale, $\boldsymbol{\bullet}$ wheat, $\boldsymbol{\Delta}$ barley). The vertical lines indicate 0.95 confidence interval

\section{Wnioski / Conclusions}

1. Stosowanie uproszczeń $\mathrm{w}$ uprawie gleby $\mathrm{w}$ formie uprawy bezorkowej może mieć wpływ na zwiększenie liczby gatunków Carabidae oraz liczebności średnich zoofagów na polach uprawnych.
2. W uprawach orkowych dominowały gatunki: Poecilus cupreus, Pterostichus melanarius, Anchomenus dorsalis i Calathus fuscipes.

3. W uprawach bezorkowych dominowały: P. cupreus, A. dorsalis, Carabus granulatus i Harpalus rufipes.

\section{Literatura / References}

Aleksandrowicz O.P. 2004. Biegaczowate (Carabidae). s. 28-42. W: „Fauna Polski - charakterystyka i wykaz gatunków” (W. Bogdanowicz, E. Chudzicka, I. Pilipiuk, E. Skibińska, red.). Muzeum i Instytut Zoologii PAN, Warszawa, I, 509 ss.

Aleksandrowicz O., Pakuła B., Mazur J. 2008. Biegaczowate (Coleoptera: Carabidae) w uprawie pszenicy w okolicy Lęborka. [Carabid beetles (Coleoptera: Carabidae) in the wheat field near Lebork]. Słupskie Prace Biologiczne 5: 15-25.

Andersen A. 2003. Long-term experiments with reduced tillage in spring cereals. II. Effects on pest and beneficial insects. Crop Protection 22 (1): 147-152. DOI: 10.1016/S0261-2194(02)00133-3.

Baguette M., Hance T. 1997. Carabid beetles and agricultural practices: influence of soil ploughing. Biological Agriculture and Horticulture 15 (1-4): 185-190. DOI: 10.1080/01448765.1997.9755193.

Barney R.J., Pass B.C. 1986. Ground beetle (Coleoptera: Carabidae) populations in Kentucky alfalfa and influence of tillage. Journal of Economic Entomology 79 (2): 511-517. DOI: 10.1093/jee/79.2.511.

Bréavult T., Bikay S., Maldès J.M., Naudin K. 2007. Impact of a no-till with mulch soil management stategy on soil macrofauna communities in a cotton cropping system. Soil and Tillage Research 97 (2): 140-149. DOI: 10.1016/j.still.2007.09.006.

Cárcamo H.A., Niemalä J., Spence J.R. 1995. Farming and ground beetles: effects of agronomic practice on populations and community structure. The Canadian Entomologist 127 (1): 123-140. DOI: 10.4039/Ent127123-1.

Eyre M.D., Luff M.L., Leifert C. 2013. Crop, field boundary, productivity and disturbance influences on ground beetles (Coleoptera, Carabidae) in the agroecosystem. Agriculture, Ecosystems and Environment 165: 60-67. DOI: 10.1016/j.agee.2012.12.009.

Gailis J., Turka I. 2014. The diversity and structure of ground beetles (Coleoptera: Carabidae) assemblages in differently managed winter wheat fields. Baltic Journal of Coleopterology 14 (1): 33-46.

Gailis J., Turka I., Ausmane M. 2017a. Soil tillage and crop rotation differently affect biodiversity and species assemblage of ground beetles inhabiting winter wheat fields. Agronomy Research 15 (1): 94-111.

Gailis J., Turka I., Ausmane M. 2017b. The most frequent ground beetles (Coleoptera: Carabidae) are differently affected by main soil treatment and crop rotation in winter fields. Acta Biologica Universitatis Daugavpiliensis 17 (1): 29-52. 
Hatten T.D., Bosque-Pérez N.A., Labonte J.R., Guy S.O., Eigenbrode S.D. 2007. Effects of tillage on the activity density and biological diversity of carabid beetles in spring and winter crops. Environmental Entomology 36 (2): 356-368. DOI: 10.1093/ee/36.2.356.

Hole D.G., Perkins A.J., Wilson J.D., Alexander I.H., Grice P.V., Evans A.D. 2005. Does organic farming benefit biodiversity? Biological Conservation 122 (1): 113-130. DOI: 10.1016/j.biocon.2004.07.018.

Holland J.M. 2004. The environmental consequences of adopting conservation tillage in Europe: reviewing the evidence. Agriculture, Ecosystems and Environment 103: 1-25. DOI: 10.1016/j.agee.2003.12.018.

Holland J.M., Luff M.L. 2000. The effects of agricultural practices on Carabidae in temperate agroecosystems. Integrated Pest Management Reviews 5 (2): 109-129. DOI: 10.1023/A:1009619309424.

Holland J.M., Reynolds C.J.M. 2003. The impact of soil cultivation on arthropod (Coleoptera and Araneae) emergence on arable land. Pedobiologia 47 (2): 181-191. DOI: 10.1078/0031-4056-00181.

Hůrka K. 1996. Carabidae of the Czech and Slovak Republics. Kabournek - Zlin, 565 pp.

Irmler U. 2003. The spatial and temporal pattern of Carabid beetles on arable fields in northern Germany (Schleswig-Holstein) and their value as ecological indicators. Agriculture, Ecosystems and Environment 98 (1-3): 141-151. DOI: 10.1016/S0167-8809(03)00076-8.

Kędzior R., Szwalec A., Mundała P., Skalski T. 2017. Zgrupowania biegaczowatych w rekultywowanych i regenerujących się spontanicznie ekosystemach leśnych na obszarach postindustrialnych. [Ground beetle assemblages in recultivated and spontaneously regenerated forest ecosystems on post-industrial areas]. Sylwan 161 (6): 512-518.

Kosewska A. 2016. Conventional and non-inversion tillage systems as a factor causing changes in ground beetles (Col. Carabidae) assemblages in oilseed rape (Brassica napus) fields. Periodicum Biologorum 118 (3): 231-239. DOI: 10.18054/pb.2016.118.3.4074.

Kosewska A., Nietupski M., Ciepielewska D., Słomka W. 2009. Czynniki wpływające na struktury zgrupowań naziemnych biegaczowatych (Col., Carabidae) w wybranych uprawach zbóż. [Factors influencing structures of assemblages of epigeic carabids (Col., Carabidae) populating some cereal plantations]. Progress in Plant Protection/Postępy w Ochronie Roślin 49 (3): 1035-1046.

Kosewska A., Nietupski M., Nijak K., Skalski T. 2016. Effect of plant protection on assemblages of ground beetles (Coleoptera, Carabidae) in pea (Pisum L.) and lupine (Lupinus L.) crops. Periodicum Biologorum 118 (3): 213-222. DOI: 10.18054/pb.2016.118.3.3911.

Kosewska A., Skalski T., Nietupski M. 2014. Effect of conventional and non-inversion tillage systems on the abundance and some life history traits of carabid beetles (Coleoptera: Carabidae) in winter triticale fields. European Journal of Entomology 111 (5): 669-676. DOI: $10.14411 /$ eje.2014.078.

Kotze D.J., Brandmayr P., Casale A., Dauffy-Richard E., Dekoninck W., Koivula M.J., Lövei G.L., Mossakowski D., Noordijk J., Paarmann W., Pizzolotto R., Saska P., Schwerk A., Serrano J., Szyszko J., Taboada A., Turin H., Venn S., Vermeulen R., Zetto T. 2011. Forty years of carabid beetle research in Europe - from taxonomy, biology, ecology and population studies to bioindication, habitat assessment and conservation. ZooKeys 100: 55-148. DOI: 10.3897/zookeys.100.1523.

Kromp B. 1999. Carabid beetles in sustainable agriculture: a review on pest control efficacy, cultivation impacts and enhancement. Agriculture, Ecosystems and Environment 74 (1-3): 187-228. DOI: 10.1016/S0167-8809(99)00037-7.

Larsson S.G. 1939. Entwicklungstypen und Entwicklungszeiten der dän Carabiden. Entomologic Meddelels 20: 270-560.

Lys J.A., Nentwig W. 1991. Surface activity of carabids beetles inhabiting cereal fields. Seasonal phenology and the influence of farming operations on five abundant species. Pedobiologia 35 (3): 129-138.

Nietupski M., Kosewska A., Markuszewski B., Sądej W. 2015. Soil management system in hazelnut groves (Corylus sp.) versus the presence of ground beetles (Coleoptera: Carabidae). Journal of Plant Protection Research 55 (1): 26-34. DOI: 10.1515/jppr-2015-0004.

Purvis G., Fadl A. 2002. The influence of cropping rotations and soil cultivation practice on the population ecology of carabids (Coleoptera: Carabidae) in arable land. Pedobiologia 46 (5): 452-474. DOI: 10.1078/0031-4056-00152.

Rainio J., Niemelä J. 2003. Ground beetles (Coleoptera: Carabidae) as bioindicators. Biodiversity and Conservation 12 (3): 487-506. DOI: $10.1023 / \mathrm{A}: 1022412617568$.

Schwerk A., Dymitryszyn I. 2017. Mowing intensity influences degree of changes in carabid beetle assemblages. Applied Ecology and Environmental Research 15 (4): 427-440. DOI: 10.15666/aeer/1504 427440.

Skłodowski J.J. 2014. Effects of top-soil preparation and broad-leaved tree mixture on carabid beetles in afforested fallow plots. Restoration Ecology 22 (1): 13-21. DOI: 10.1111/rec.12034.

Sunderland K.D. 2002. Invertebrate pest control by carabids. p. 165-214. In: "The Agroecology of Carabid Beetles" (J.M. Holland, ed.). Intercept, Andover, Hampshire, UK, 356 pp. ISBN 1-898298-76-9.

Tamutis V., Monsevičius V., Pekarskas J. 2004. Ground and rove beetles (Coleoptera: Carabidae, Staphylinidae) in ecological and conventional winter wheat fields. Baltic Journal of Coleopterology 4 (1): 31-40.

Thiele H.U. 1977. Carabid Beetles in their Environments. A Study on Habitat Selection by Adaptation in Physiology and Behavior. Zoophysiology and Ecology 10. Springer-Verlag, Berlin, 369 pp.

Twardowski J. 2010. Wpływ uproszczeń w uprawie roli pod pszenicę ozimą na zgrupowania stawonogów epigeicznych i glebowych. Monografia. Wydawnictwo Uniwersytetu Przyrodniczego we Wrocławiu, 141 ss.

Twardowski J.P., Pastuszko K. 2008. Siedliska brzeżne w agrocenozie pszenicy ozimej jako rezerwuary pożytecznych biegaczowatych (Col., Carabidae). [Field margins in winter wheat agrocenosis as reservoirs of beneficial ground beetles (Col., Carabidae)]. Journal of Research and Applications in Agricultural Engineering 53 (4): 123-127. 